\title{
The Effect of Workload on the Job Stress of Nurses in Outpatient Care Unit of Public Hospital Surabaya, Indonesia
}

\author{
Satria Sandianto ${ }^{1}$, Abdul Rohim Tualeka ${ }^{1}$, Diah Indriani ${ }^{2}$ \\ ${ }^{\prime}$ De partment of Occupational Health and Safety, ${ }^{2}$ De partment of Biostatistics and Demography, \\ Airlangga University, Surabaya, Indonesia
}

\begin{abstract}
Nurses is one of profession who have high risk to suffered of job stress. Public hospital Surabaya is hospital which is teaching hospital type and as a reference hospital healths program from government of National Health Insurance in Surabaya city. The effect of this conditions are increase number of patients and nurse's workload. This case also increasing the opportunity of risk nurse to job stress.

This study aims to assess the prevalence of job stress among nurse in outpatient unit and to investigate the correlation between job stress with individual factors and workload. This study is quantitative research with cross- sectional design, study was conducted during January 2017 and the respondents were recruited by using a total population were 26 nurses. Technique of data collection was based on questionnaire and callorimeter to measure a physical workload. To know the level of influence of each risk factor on the job stress at nurse in outpatient unit then conducted with frequency distribution, and crosstab, then analyzed with the test of logistic regression.

The results of the analysis showed no influence significant between the age, gender, physical workload with job stress. The result of logistic regression showed that there is significant relation of mental workload. Based on result showed mental workload is the dominant factor that influence the job stress. The odds of which is 39,539 times higher at nurses who have major mental workload. Based on these results need efforts to increase cooperation among a nurse with others unit which is related units to work system becomes an effective and efficient, to improve the social support among the co-worker, and to improve the commitment of all staff in the hospital to be more punctual on performing their duty.
\end{abstract}

Keywords: murse, workload, job stress

\section{INTRODUCTION}

Nurse is one of medical staff in hospitals who give medical services to support the treatment of patients. Nurses as a medical staff in hospital have a high work demand on their role in the hospital. This high demand of work can affect their workload. Factors that can affect the workload of nurses are the patient condition that is constantly changing, the average duration (hour) needed to give direct treatment to patiens that is more than the nurse's ability, also the documentation of nursery care ${ }^{1 .}$

A workload arises from an interaction between a call of duty, the work environment, skill, behavior, and perception of the duty. Workload also can be defined operationally on several factors such as the task demand or the performed effort to finish the task ${ }^{2}$ Workload is not only on physical form, but also in mental one. Physical workload such as the burden of lifting, carrying, maintaining, and pushing objects, while the mental workload such as the weight of performing mental activities and perceptual such as memorizing, searching, working under time pressure, and interacting with patients to explain about medical treatments.

The survey of Self-Reported Workrelated Illness (SWI) shows that nurses have a high prevelance of stress related to the work ${ }^{3}$.

Job stress occurs in many workers in the health sector. The responsibility towards human on medical field cause workers more vulnerable to stress ${ }^{4}$. All of 
profesional staffs in a hospital have a high risk of stress, but the nurse have a higher risk of stress ${ }^{5,6}$.

In general, hospital treatment consists of an inpatient care unit and an outpatient care unit. In outpatient care unit, a nurse is responsible to assist the doctor on preparing the tools, measuring patients body weight, measuring patients blood pressure, and provide the needed medicines during the treatment. They work under the instruction of the doctor.

The frequency of meeting between nurses and patients in outpatient care unit is lesser than the nurse of inpatient care. The nurse in outpatient care meets the patient on the day of check-up only, then the nurse more of ten meets with the doctor who checks the patient. Common problems faced by the nurses in outpatient care unit are explaining about the medical services to patients and also handling the complaint from the patient about those services, administrative work, the doctors who come late and leave early. All of those things can become a source of stress for the nurses.

Nurses in Jimma Hospital, Ethiopia, who work in outpatient care unit experience a stress higher than the nurse from other units, and the major sources of that stress is the workload ${ }^{7}$. Another research on 40 nurses in outpatient care shows that $55 \%$ of nurses experience stress at medium up to high level, and the most determining factor of that stress is workload ${ }^{8}$.

Recent studies have shown an association between individual characteristic, mental workload and job stress in nurse at outpatient unit. Hence this study was aimed to assess the association of job stress among nurse at oupatient unit and to investigate the factors relating job stress and provide recommendation for preventing the risk factors.

\section{MATERIAL AND METHODE}

\section{Participants}

The present study was a cross-sectional analysis done among nurses at thirteen outpatient care unit of public hospital Surabaya during January 2017 provided written informed consent to complletion of a self administered anonymous questionnaire.
Full time nurses $(n=26)$ were selected by using a total sampling method. Inclussion criteria were as follows: the subject should be working in the current job for at least six months. Permission from the respective organization for doing the study was taken.

\section{Procedure}

The following tools were used during the study: questionaire and calorimeter. Structured questionnaires were administered to obtain information about workload factors which causing stress in workplace. It consist of three sections of questions.

The first section requested for individual capacity like age, job section, and gender.

The second section requested for mental workload scales using the NASA TLX Questionnaire developed by The Human Performance Group at NASA's Ames Research Center. The questionnaire includes six mental workload scales regarding quantitative load (Physical workload, efforts, etc).

The third section was designed to assess Job stress using HSE Management Standards Indicator Tool Questionnaire developed by Health Safety Executive.

The study subjects were examined for their physical workload by using a Calorimeter heart rate watch.

Mental workload are classified according to the total average of weighted workload score from the answer of NASA TLX and job stress is classified according to total score of answer of the questionnaire into category of light job stress, medium job stress, high job stress, and very high job stress.

Data analysis

To know the level of influence of each risk factor to occurrence of job stress on the nurse at oupatient unit it is conducted to univariate analyze with the frequency distribution and crosstab, and analyze the bivariate with the test of logistic regression. The level of significance considered was 0.05 . All analysis were conducted using the Portable SPSS PASW Statistics 18.0. 


\section{FINDINGS}

\begin{tabular}{|c|c|c|c|c|c|c|}
\hline \multirow[b]{2}{*}{ Variable } & \multicolumn{4}{|c|}{ Occurance of Job Stress } & \multirow[b]{2}{*}{ PValue } & \multirow[b]{2}{*}{$\begin{array}{l}\text { Odds } \\
\text { Ratio }\end{array}$} \\
\hline & $\begin{array}{l}\text { Light } \\
(n=12)\end{array}$ & $\begin{array}{l}\text { Medium } \\
(\mathrm{n}=14)\end{array}$ & $\begin{array}{l}\text { High } \\
(\mathrm{n}=0)\end{array}$ & $\begin{array}{l}\text { Very High } \\
(\mathrm{n}=0)\end{array}$ & & \\
\hline \multicolumn{7}{|l|}{ Age (years old) } \\
\hline $36-45$ & $6(50 \%)$ & $4(28,6 \%)$ & $0(0 \%)$ & $0(0 \%)$ & 0,989 & \\
\hline $46-55$ & $6(50 \%)$ & $9(64,3 \%)$ & $0(0 \%)$ & $0(0 \%)$ & 0,882 & 1,193 \\
\hline $56-65$ & $0(0 \%)$ & $1(7,1 \%)$ & $0(0 \%)$ & $0(0 \%)$ & 1,000 & $1 \mathrm{E}+009$ \\
\hline \multicolumn{7}{|l|}{ Gender } \\
\hline Male & $4(33,3 \%)$ & $3(21,4 \%)$ & $0(0 \%)$ & $0(0 \%)$ & & \\
\hline Female & $8(66,7 \%)$ & $11(78,6 \%)$ & $0(0 \%)$ & $0(0 \%)$ & 0,225 & 6,681 \\
\hline \multicolumn{7}{|c|}{ Physical Workload } \\
\hline Light & $9(75 \%)$ & $12(85,7 \%)$ & $0(0 \%)$ & $0(0 \%)$ & & \\
\hline Medium & $3(25 \%)$ & $2(14,3 \%)$ & $0(0 \%)$ & $0(0 \%)$ & 0,809 & 1,460 \\
\hline Heavy & $0(0 \%)$ & $0(0 \%)$ & $0(0 \%)$ & $0(0 \%)$ & & \\
\hline \multicolumn{7}{|c|}{ Mental Workload } \\
\hline Light & $0(0 \%)$ & $0(0 \%)$ & $0(0 \%)$ & $0(0 \%)$ & & \\
\hline Medium & $0(0 \%)$ & $0(0 \%)$ & $0(0 \%)$ & $0(0 \%)$ & & \\
\hline Slightly High & $10(83,3 \%)$ & $2(14,3 \%)$ & $0(0 \%)$ & $0(0 \%)$ & & \\
\hline High & $2(16,7 \%)$ & $12(85,7 \%)$ & $0(0 \%)$ & $0(0 \%)$ & 0,005 & 39,539 \\
\hline Very High & $0(0 \%)$ & $0(0 \%)$ & $0(0 \%)$ & $0(0 \%)$ & & \\
\hline
\end{tabular}

\section{Occurance of Job Stress}

The number of nurses in outpatient care unit of Public Hospital Surabaya who experience light stress is 12 respondents (46.2\%), medium job stress is 14 respondents $(53.8 \%)$, and there are no nurses who have a high or very high level of stress.

Workload is one of the stressor which can cause a stress to the respondent. The absence of respondent who experiences a high or very high level of stress even if there is a high stressor caused by the stress coping mechanism possessed by the respondent. The stressor at work environment wether can directly or indirectly affect the worker is depend on the coping mechanism performed by the worker, if the worker are unsuccessful on performing the coping mechanism, then it can manifest on the experience of job stress ${ }^{9}$.

\section{Age}

This research shows that the majority of respondent who experience medium level stress is respondents in the age of $46-55$ years old $(64,3 \%)$. People at those age is classified in a middle adulthood group, and at this group of people have better awareness about things they

can do to alter the condition of high stress and also have more effective strategy to prevent and minimize the stress ${ }^{10}$.

The test of logistic regression shows that $p$ value $>0.05$, it means that the age variable has unsignificant effect on the job stress of the nurses of outpatient care unit. This research is similar to the previous research which shows that there is no significant relations between the age variable and job stress ${ }^{1}$. Job stress can be caused by other factors besides the age variable, a people who more mature is suppose to be have better control of their stress because they have a good social skill.

\section{Gender}

The research shows that respondents who experience medium level of stress are mostly women $(78,6 \%)$. Both man and woman can experience stress, but the woman has higher possibility to experience job stress than man. The occurrence of stress on woman can happen because of the condition and the changes of their biological, psychological, and social aspects ${ }^{12}$. Besides, it can be 
caused by the fact that the woman emotions is more unstable than $\operatorname{man}^{13}$.

Logistic regression test shows that $p$ value $>0.05$ which means that gender has no effect to job stress, this is because the good relationship among the nurses, especially on the female nurses. The nurses provide services for about an average of five hours a day and the three other hours used to perform the administrative works. When performing administrative work, female nurses able to communicate more freely even about the things unrelated to the work, this condition is supported by the amount of female nurses that is more than male nurse, so that female nurse feels a social support from their co-worker. That kind of social support is important and can contribute to the improvement of work performance and the decrease of job stress level ${ }^{14}$. In this research, there are other factors that can contribute to job stress besides the gender.

\section{Physical workload}

Job stress on medical staff, including the nurses, can be caused by many factors, one of them is overwhelming workload ${ }^{1}$ s. In this research, physical workload is defined by the amount of calory used by the respondents during the work. The respondents who exercise energy for about 100-200 kcal per hour is considered as a performing a light work, 201-350 kcal per hour is in medium category, and $351-500$ is considered as heavy work ${ }^{16}$.

In this research, the majority of respondents fall into light category and there is none who fall into heavy category, please see the table above for complete result. The statistic test result shows that $p$ value $>0.05$ which mean that the physical workload has no influence on the respondent job stress. Base on the observation result on the respondent, it is known that when provide services to the patient, respondent can perform their job by sitting because the task is administrative and considered as light physicial work. The respondent doesn't perceive light physical workload as a thing that can cause job stress.

\section{Mental workload}

Besides the physical workload, the mental workload also need attentions. Physiologically, mental activities look like a simple task which doesn't require much calory. But, from moral and responsibility perspective, it is clearly heavier than the physical activites because it actively exercising the brain than the muscle. In this research, there is no respondent who have light, medium, or very high mental workload.

The respondent who have high mental workload, the majority of them have medium job stress $(85.7 \%)$, the regression test result shows that $\mathrm{p}$ value $<0.05$ which means that the mental workload can contribute to the respondent job stress. When in duty, a nurse need physical effort and mentally to finish their task ${ }^{17}$.

Public Hospital Surabaya is one of teaching hospital in Surabaya city, in there we can find medical students who pursue their education. The presence of those medical students can give extra burden to the respondents because they have to give instructions regarding the procedures, there are times when the respondents have to clean up the medical tools and ensure their safety because it was left untidied by the students. The previous research shows that a teaching hospital is closely related to the workload of nurses because it give unfavorable effects on the nurses workload ${ }^{18 .}$

In this research, the respondent often performs administrative works, taking care of so many patients while the doctors themselves was busy so they cann't be punctual, those conditions can give adverse effects on the nurses because those can trigger the complaints from the patients to the nurses. Base on the interview with respondents, the other problems are staffs who late on delivering the patients medical record. This problem gives some kind of time pressure on the nurses since their time allocation for servicing the patients become less. The high mental workload in this research is the main factor that can cause stress on the respondents. Base on the previous research, it is known that nurses have high mental workload ${ }^{19}$.

\section{CONCLUSION}

Age factor, gender, and physical workload are not affecting the occurrence of stress on the nurses in outpatient care unit in Public Hospital Surabaya. The most affecting factor is the mental workload. The respondents in this research have a slightly high and high mental workload, there is no respondent who have a light or very high mental workload.

The research result shows that the respondents who have high mental workload are 39 times more vulnerable to experience a medium job stress than the respondent who have a slightly high mental workload. The total 
amount of patient, the presence of medical students, the complaint from patient and also the time pressure are the mental workloads that cause stress on the respondent. Therefore, respondents need to improve the cooperation among the nurses from other unit in order to make the work system more effective and efficient, to improve the social support among the co-worker, and to improve the commitment of all staff in the hospital to be more punctual on performing their duty.

\section{Conflict of Interest: None}

\section{Source of Funding: Self}

Ethical Clearance: The study was approved by the institutional Ethical Board of the Public Health, Airlangga University.

All subjects were fully informed about the procedures and objectives of this study and each subject prior to the study signed an informed consent form.

\section{REFERENCES}

1. Munandar A.S. Psikologi industri dan organisasi. Edisi 1, Jakarta: UI Press. 2001.

2. Tarwaka. Ergonomi Industri. Surakarta: Harapan Press. 2014.

3. European Agency For Safety And Health At Work. Annual Report 2009. Luxembourg: EASHW.

4. Taylor. Health Psychology. Los Angeles: Mc Graw Hill. 2006.

5. Charnley E. Occupational Stress in the Newly Qualified Staff Nurse. 1999. Nursing Standard, 33.

6. Gelsema TI, Van der Doef, M, Maes, S, Akerboom, S, Verhoeven C. Job stress in the nursing profession: The influence of organizational and environmental conditions and job characterist ics. International Journal of Stress Management. 2005. 222-240.

7. Dagget T, Molla A, Belachew. Job Related Stress Among Nurses Working in Jimma Zone Public Hospitals South West Ethiopia. BMC Nursing. 2016. 15:39.

8. Woonhwa Ko, Larson NK. Stress Levels of Nurses in Oncology Outpatient Units. Clinical Journal of Oncology Nursing. 2016. Vol. 20, No. 2, April 2016.
9. Noeroel W. Pengembangan Model NIOSH Tentang Unsafe Action Pada Kondisi Job Stress Pekerja Bagian Produksi di Perusahaan Konstruksi Baja. Dissertation. Public Health, Airlangga University, Surabaya. 2015.

10. Papalia DE, Olds SW, Feldman R. Human Development edisi 10. Jakarta: Salemba Humanika. 2009.

11. Apeksha G, Mahadeo S. Occupational Stress and Job Satisfaction among Nurses. International Journal of Science and Research (IJSR). 2014. Vol. 3 Issue 4, April 2014.

12. Sarwono, (2006). Hubungan Masa Kerja Dengan Stres Kerja Pada Pustakawan Universitas Gajah Mada. Berkala Ilmu Perpustakaan dan Informasi. Vol. 31. No. 1, 2006.

13. Russeng S, Usman M, Saleh L. Stres Kerja Pada Perawat Di Instalasi Rawat Inap Rumah Sakit Dr.Tadjuddin Chalid Makassar. Media Public Health Indonesia. 2007. Vol. 3 No.1, ISSN: 02162482, Juli 2007.

14. AbuAlRub, R. F. Job Stress, Job Performance, and Social Support Among Hospital Nurses. Journal of Nursing Scholarship. 2004. 36: 73-78. doi: 10.1111/j.1547-5069.2004.04016.x

15. National Institute for Occupational Safety and Health, (2008). Exposure To Stress: Occupational Hazards in Hospitals. Department Of Health And Human Services. Publication No. 2008-136.

16. Badan Standarisasi Nasional. Penilaian Beban Kerja Berdasarkan Tingkat Kebutuhan Kalori Menurut Pengeluaran Energi. Jakarta. 2009.

17. Cox T, Griffith A. Work Related Stress in Nursing: Controlling the Risk to Health: International Labour Office Geneva. 1996.

18. Mohammadi M, Mazloumi A, Kazemi Z, Zeraati H. Evaluation of Mental Workload among ICU Ward's Nurses. Health Promot Perspect. 2015; 5(4): 280-287.

19. Hoonakker P, Carayon P, Gurses A, Brown R, McGuire K, Khunlertkit A, Walker JM. (2011). Measuring Workload Of ICU Nurses With A Questionnaire Survey: The NASA Task Load Index (TLX). IIE Trans Healthc Syst Eng.2011; 1(2): 131-143. 